\title{
PENINGKATAN HASIL BELAJAR MATEMATIKA SISWA MELALUI PENDEKATAN MATEMATIKA REALISTIK PADA OPERASI HITUNG DI KELAS II SD NEGERI 22 LUBUK ALUNG KABUPATEN PADANG PARIAMAN
}

\author{
Yuli Harfi
}

\begin{abstract}
Abstrak
Penelitian ini dilatar belakangi oleh adanya kenyataan di lapangan pembelajaran di kelas II Sekolah Dasar (SD) belum menggunakan pendekatan realistik. Berdasarkan pengamatan peneliti di SD Negeri 22 Lubuk Alung Kabupaten Padang Pariaman bahwa guru kelas II SD mengajarkan matematika masih dengan cara tradisional dengan arti kata belum mengaitkan pembelajaran dengan kehidupan nyata siswa. Tujuan penelitian ini adalah mendeskripsikan dan mendapatkan informasi tentang pembelajaran operasi hitung campuran dengan pendekatan realistik. Pendekatan yang digunakan adalah pendekatan kualitatif yang terdiri dari dua siklus meliputi empat tahap yaitu perencanaan, tindakan, pengamatan, dan refleksi. Data penelitian ini berupa informasi tentang proses dan data hasil tindakan yang diperoleh dari hasil pengamatan, hasil wawancara, dan tes. Subjek peneliti adalah guru, peneliti (praktisi) dan siswa kelas II yang berjumlah 25 orang. Analisis data dilakukan dengan menggunakan model analisis data kualitatif dan kuantitatif. Hasil belajar matematika siswa dengan menggunakan pendekatan matematika realistik pada siklus I dan II mengalami peningkatan di mana nilai rata-rata pada siklus I diperoleh rata-rata 77,2 dan pada siklus II rata-rata 88,2. Dengan demikian dapat disimpulkan bahwa pembelajaran matematika dengan menggunakan pendekatan matematika realistik dapat meningkatkan hasil belajar matematika siswa kelas II.
\end{abstract}

Keyword: Matematika Realistik, Operasi Hitung

Copyright (C) 2016 IICET (Padang - Indonesia) - All Rights Reserved Indonesian Institute for Counseling, Education and Theraphy (IICET)

\section{PENDAHULUAN}

Salah satu karakteristik matematika adalah mempunyai sifat yang abstrak, ini menyebabkan banyak siswa mengalami kesulitan dalam belajar Matematika. Jenning (dalam Arjuna 2009:1) menyatakan "kebanyakan siswa mengalami kesulitan dalam mengaplikasikan matematika ke dalam situasi kehidupan riil". Hal lain yang menyebabkan sulitnya matematika bagi siswa adalah karena pembelajaran matematika kurang bermakna, jadi pemahaman konsep yang benar sangatlah penting. Untuk memahami konsep yang baru, diperlukan prasyarat konsep sebelumnya agar pembelajaran matematika dimengarti oleh siswa, maka perlu penanaman konsep awal yang benar dari guru terutama guru SD.

Zainurie (2007:2) "Rendahnya prestasi matematika siswa disebabkan oleh faktor siswa yaitu mengalami masalah secara komprehensif atau secara persial dalam matematika". Hal inilah yang menyebabkan siswa kesulitan dalam matematika, dikarenakan guru kurang mengaitkan pembelajaran dengan kehidupan dalam kegiatan sehari-hari siswa dan kurang mengkonkretkan pembelajaran matematika sehingga siswa menganggap matematika itu sulit, terutama bagi siswa di kelas II SD yang harus paham tentang konsep-konsep matematika. Marpaung (dalam Rosna, 2006:2) menyatakan bahwa: Buruknya pengajaran matematika di Indonesia disebabkan pendekatan cendrung mementingkan hasil dari pada proses, kaku dan terpisah-pisah, dimana pengajaran terlalu mekanistik. Perlu dipikirkan pengajaran yang baru dimana siswa lebih banyak diajak menemukkan persoalan matematika dari kejadian alam yang paling dekat dengan realitas kehidupan sehari-hari mereka.

Pembelajaran matematika haruslah bermakna bagi siswa, supaya siswa tidak mengalami kesulitan dalam mengaplikasikan matematika dalam situasi kehidupan nyata siswa. Guru dalam mengajar matematika di kelas harus mengaitkan pembelajarannya dengan skema yang telah dimiliki oleh siswa dan siswa harus diberikan kesempatan untuk menemukan kembali dan mengkonstruksi sendiri ide-ide matematika tersebut. 
Namun dalam penyampaian pembelajaran matematika umumnya guru tidak mengaitkan dengan skema yang telah dimiliki oleh siswa dan siswa kurang diberikan kesempatan untuk menemukan kembali dan mengkonstruksi sendiri ide-ide matematika, sehingga menyebabkan siswa belajar secara pasif. Van De Henvel (dalam Arjuna, 2009:2) menyebutkan "bila anak belajar matematika terpisah dari pengalaman mereka sehaihari maka anak cepat lupa dan tidak dapat mengaplikasaikan matematika". Konsekuensinya apabila siswa diberikan soal latihan yang berbeda dengan contoh soal, siswa sering membuat kesalahan dalam memberikan jawaban. Hal ini disebabkan karena guru memberikan satu contoh soal tanpa menambah dengan soal yang lain kemudian langsung memberikan soal latihan berbeda dengan contoh soal.

Dari hasil observasi peneliti di SDN 22 Lubuk Alung Kabupaten Padang Pariaman di kelas II Kamis 27 Februari 2014, di ketahui siswa mengalami kesulitan dalam belajar matematika tentang pembelajaran operasi hitung campuran, terutama yang berkaitan dengan perkalian dan pembagian. Pada saat guru menjelaskan pelajaran tersebut di depan kelas siswa mengerti, tapi bila siswa diberikan soal latihan yang berbeda siswa mengalami kesulitan dalam menyelesaikan soal tersebut. Seperti pada waktu guru menjelaskan pembelajaran tentang perkalian siswa mengerti setelah guru membuat soal pembagian dan perkalian dalam bentuk operasi hitung campuran siswa mulai bingung. Hal ini menyebabkan rendahnya hasil pembelajaran siswa, untuk meningkatkan hasil pembelajaran matematika tergantung dari bagaimana guru melaksanakan pembelajaran. Guru harus menciptakan pembelajaran yang menyenangkan bagi siswa. Salah satu cara yaitu dengan menerapkan pendekatan matematika realistik.

Pembelajaran matematika dengan pendekatan matematika realistik, akan memberikan kesempatan kepada siswa untuk menemukan dan mengkonstruksi kembali konsep matematika sehingga siswa mempunyai konsep pengertian yang kuat. Sesuai dengan pernyataan dari Gravemeijer (dalam Sutarto, 2005:9) menyatakan "siswa perlu diberi kesempatan untuk menemukan kembali ide-ide dan konsep matematika dengan bimbingan orang dewasa". Hal tersebut dapat dilakukan dengan mengupayakan berbagai kondisi dan situasi serta permasalahan-permasalahan yang realistik, sehingga pembelajaran bermakna dan membuat siswa tertarik untuk belajar matematika serta dapat meningkatkan hasil pembelajaran.

\section{METODELOGI PENELITIAN}

Penelitian ini akan dilaksanakan di kelas II SDN 22 Lubuk Alung Kabupaten Padang Pariaman. Penelitian tindakan kelas ini dilaksanakan di SD Negeri 22 Lubuk Alung Kabupaten Padang Pariaman. Sebagai subjek dalam penelitian ini adalah siswa kelas II, yang terdaftar pada semester II tahun ajaran 2013/2014, dengan jumlah siswanya 25 orang, dengan siswanya 13 orang perempuan dan 12 orang laki-laki. Penelitian ini dilaksanakan pada semester II di SD tahun ajaran 2013/2014. penelitian ini dilakukan pada bulan Mei-Juni 2014 yang terdiri dari siklus I dengan 2 x pertemuan dan siklus II dengan 2 x pertemuan.

Pendekatan yang dipergunakan dalam penelitian ini adalah pendekatan kualitatif dan kuatitatif, karena peneliti ingin mengamati fenomena yang terjadi di dalam kelas. Jenis penelitian ini adalah penelitian tindakan kelas yaitu proses yang dilakukan perorangan atau kelompok yang menghendaki perubahan dalam situasi tertentu.

Menurut Kemmis Taggart (dalam Akhmad, 2009:6) proses penelitian tindakan merupakan daur ulang atau siklus yang dimulai dari aspek mengembangkan perencanaan, melakukan tindakan sesuai rencana, melakukan observasi terhadap tindakan dan melakukan refleksi yaitu perenungan terhadap perencanana kegiatan tindakan kelas dan kesuksesan hasil yang diperoleh sesuai dengan prinsip umum penelitian tindakan setiap tahapan dan siklusnya selalu secara parsipasitoris dan kolaboratif antara peneliti dan praktisi (guru dan kepala sekolah) dalam sistem persekolahan.

Penelitian ini di awali dengan adanya observasi awal/studi pendahuluan terhadap proses pembelajaran di SDN 22 Lubuk Alung Kabupaten Padang Pariaman. Kegiatan ini dilaksanakan untuk mengetahui permasalahan yang dihadapi guru dan siswa yang berkaitan dengan proses pembelajaran matematika di kelas II SDN 22 Lubuk Alung Kabupaten Padang Pariaman.

Data penelitian berupa observasi, hasil tes, diskusi dan dokumentasi dari setiap tindakan perbaikan pembelajaran matematika melalui pendekatan matematika realistik siswa kelas II SD yang diteliti. Data tersebut berisi tentang hal-hal yang berkaitan dengan perencanaan, pelaksanaan, dan hasil pembelajaran yang berupa informasi berikut:

a. Pelaksanaan pembelajaran yang berhubungan dengan perilaku guru dan siswa yang meliputi intereksi belajar-mengajar antara guru dan siswa, siswa dengan siswa, siswa dengan guru dalam proses pembelajaran matematika.

b. Evaluasi pembelajaran matematika yang berupa evaluasi proses maupun evaluasi hasil

c. Hasil tes siswa dilaksanakan sesudah pelaksanaan tindakan pembelajaran matematika. 
Sumber data penelitian adalah proses pembelajaran matematika di kelas II SDN 22 Lubuk Alung Kabupaten Padang Pariaman, yang meliputi perencanaan pembelajaran, pelaksanaan pembelajaran, kegiatan evaluasi pembelajaran prilaku guru dan siswa selama proses pembelajaran. Data diperoleh dari subjek yang diteliti, yakni guru dan siswa kelas II SDN 22 Lubuk Alung Kabupaten Padang Pariaman .

Data penelitian ini dikumpulkan dengan observasi, hasil tes, diskusi dan dokumentasi. Untuk masingmasing akan diuraikan sebagai berikut:

a) Observasi dilakukan untuk mengamati kelas tempat berlangsungnya pembelajaran matematika. Dengan berpedoman pada lembar penilaian rencana pelaksanaan pembelajaran, guru mengamati apa yang terjadi selama proses pembelajaran. Unsur-unsur yang menjadi sasaran pengamatan bila terjadi dalam proses pembelajaran ditandai dengan memberi ceklist di kolom yang ada pada lembar observasi. Guru di sini berperan sebagai observer, yang melaksanakan pengamatan kegiatan yang ada di dalam perencanaan. Dan peneliti berperan sebagai partisipan yakni sebagai pelaksana kegiatan pembelajaran matematika kelas II SD.

b) Diskusi dilakukan yang berkaitan dengan pelaksanaan perencanaan pembelajaran matematika. Hasil diskusi ini digunakan sebagai bahan untuk perbaikan perencanaan dan pelaksanaan yang akan dilakukan pada siklus berikutnya. Tes di gunakan untuk memperkuat data observasi yang terjadi di dalam kelas terutama pada butir penguasaan materi pembelajaran dari unsur siswa. Hal ini dilakukan untuk memperoleh data yang akurat atas kemampuan memahami pembelajaran matematika.

c) Dokumentasi diambil pada saat peneliti melakukan penelitian dalam proses pembelajaran matematika dengan menggunakan pendekatan matematika realistik. Dari diskusi dalam proses pembelajaran akan diperoleh masukan-masukan yang bersifat membangun bagi penelitian ini.

Prosedur pengumpulan data yang dilakukan berdasarkan bentuk data yang ingin diperoleh, data penelitian ini dikumpulkan dengan menggunakan tes, observasi aktivitas guru dan siswa, serta pengambilan gambar pada saat pembelajaran belangsung. Untuk masing-masinng uraiannya adalah sebagai berikut:

a) Tes dilakukan untuk informasi tentang kemampuan siswa dalam memahami pembelajaran matematika. Tes ini dilakukan pada awal dan setiap akhir tindakan,

b) Observasi, bertujuan untuk mengamati kegiatan guru dan siswa selama kegiatan pembelajaran. Hal ini dilakukan untuk mengetahui adanya kesesuaian antara rencana dan pelaksanaan tindakan, serta mengkaji sejauh mana pemberian tindakan menghasilkan perubahan sesuai yang dikehendaki peneliti.

Dalam penelitian peningkatan pembelajaran matematika melalui pendekatan matematika realistik pada siswa kelas II SDN 22 Lubuk Alung Kabupaten Padang Pariaman, peneliti adalah instrumen utama sebagai penentu berhasilnya penelitian karena peneliti yang akan memberikan kesimpulan terhadap penelitian ini.

Data yang diperoleh dalam penelitian menggunakan model analisis data kualitatif. Model data kualitatif oleh Miles dan Huberman (dalam Akhmad, 2009:8) yakni analisis data dimulai dengan menelaah sejak pengumpulan data sampai seluruh data terkumpul. Data tersebut direduksi berdasarkan masalah yang diteliti, diikuti penyajian data dan terakhir penyimpulan atau verifikasi.

Tahap analisis yang demikian dilakukan berulang-ulang begitu data selesai dikumpulkan pada setiap tahap pengumpulan data dalam setiap tindakan. Tahap analisis data tersebut dapat diuraikan sebagai berikut menelaah data yang terkumpul dengan melakukan transkripsi hasil pengamatan, penyeleksian dan pemilihan data.

Kemudian data tersebut direduksi melalui pengkategorian dan pengklasifikasian sesuai dengan fokus masing-masing. Sehingga dapat menyeleksi mana yang relevan dan mana yang tidak relevan. Kemudian data tersebut disajikan dengan cara mengorganisasikan informasi yang telah direduksi melalui rangkuman yang disajikan secara terpadu.

\section{HASIL DAN PEMBAHASAN PENELITIAN \\ HASIL PENELITIAN}

\section{Siklus I}

Observasi keberhasilan tindakan diamati selama dan sesudah tindakan dilaksanakan. Hal ini dilaksanakan untuk mendapatkan informasi dari observer terhadap pelaksanaan pembelajaran pada siklus I baik pelaksanaan, evaluasi dan hasil yang diperoleh oleh siswa.

Berdasarkan pengamatan observer yaitu guru kelas II dan hasil diskusi dengan peneliti, pada tindakan siklus I ditemukan masih ada siswa yang belum ikut secara aktif menyelesaikan masalah realistik yang diberikan. Selain itu juga ditemukan adanya beberapa siswa yang belum berani mengemukakan pendapatnya, siswa lebih suka mendengar dan memperhatikan temannya berdiskusi. 
Evaluasi hasil yang diperoleh pada siklus I mencapai 77,2\%. Hal ini disebabkan ada sebagian yang siswa masih mengalami kesulitan dalam menjawab soal mengenai perkalian dan pembagian dan mengenai operasi hitung campuran dalam pembelajaran melalui pendekatan matematika realistik.

Dari hasil diskusi dengan guru kelas, maka diperoleh hal-hal sebagai berikut:

1) Secara umum pelaksanaan pembelajaran telah berjalan sesuai dengan rencana pembelajaran yang disusun karena telah mencerminkan model pendekatan realistik.

2) Belum semua siswa aktif, maka aktifitas siswa selama proses pembelajaran perlu ditingkatkan.

3) Guru perlu meningkatkan cara memotivasi siswa dalam mengeluarkan pendapat karena masih banyak siswa yang belum berani menanggapi hasil diskusi kelompok temannya.

4) Guru perlu membimbing siswa dalam menyimpulkan materi pembelajaran karena siswa banyak yang tidak membuat kesimpulan materi pelajaran.

5) Pembelajaran siklus I memerlukan waktu lebih dari waktu yang direncanakan, karena waktu banyak terpakai oleh pengaturan kelompok

6) Pelaksanaan pembelajaran masih belum optimal, karena masih ada siswa yang belum paham memindahkan permasalahan kebentuk matematika.

7) Hasil tes akhir dan ketuntasan belajar siswa menunjukan lebih dari separoh siswa yang belum tuntas belajarnya. Masih ada beberapa siswa yang masih mendapatkan nilai di bawah rata-rata. Pada umumnya siswa mengalami kesulitan dalam langkah melakukan operasi hitung campuran. Setelah ditanyakan kepada siswa ternyata banyak yang menjawab tidak paham yang mana yang dikerjakan terlebih dahulu.

Berdasarkan refleksi di atas dan hasil diskusi dengan kepala sekolah, pembelajaran yang diharapkan pada pembelajaran siklus I belum tercapai dengan baik. Upaya menggunakan pendekatan realistik dapat menentukan langkah-langkah proses pembelajaran yang akan ditargetkan pada siklus II. Untuk peningkatan aktivitas dan hasil belajar siswa agar sesuai dengan yang diharapkan maka perlu dirumuskan tindakan pada siklus II antara lain:

1) Memotivasi siswa agar aktif berdiskusi dalam kelompok.

2) Untuk menghemat waktu, siswa dikelompokan dengan teman sebangkunya dan ini juga bertujuan supaya siswa lebih aktif dalam melakukan kegiatan.

3) Lebih membimbing siswa untuk paham memindahkan permasalahan ke bentuk matematika.

4) Memotivasi siswa untuk menanggapi hasil diskusi kelompok temannya.

5) Membimbing siswa menyimpulkan materi pelajaran.

6) Siswa mampu mengerjakan evaluasi yang diberikan guru dengan baik dan benar.

Bersama observer peneliti mendiskusikan perencanaan untuk siklus berikutnya. Berdasarkan pengamatan, dan hasil tes maka tujuan yang diharapkan pada pembelajaran siklus I belum tercapai. Dengan demikian upaya menerapkan strategi pembelajaran berbasis masalah dapat direncanakan langkah-langkah proses pembelajaran yang akan ditargetkan pada siklus II. Dengan demikian rencana perbaikan ditargetkan pada kendala yang ditemui pada siklus I, dan akan dilaksanakan pada siklus II.

\section{Siklus II}

Hasil analisis refleksi pada siklus I menunjukkan keberhasilan penelitian belum mencapai tujuan yang diharapkan, hal ini dikarenakan karena kurangnya sistematika dalam pelaksanaan dengan perencanaan yang telah dibuat. Karena itu pembelajaran dilanjutkan dengan siklus II. Pembelajaran siklus II diberikan agar siswa dapat melakukan operasi hitung campuran perkalian dan pembagian bilangan dua angka dengan menggunakan pendekatan matematika realistik. Pembelajaran siklus II dilaksanakan dalam dua kali pertemuan dengan alokasi waktu $5 \times 35$ menit.

Indikator yang diharapkan pada pertemuan I adalah: 1) mengalikan bilangan dua angka 2) membagi bilangan dua angka. Sedangkan indikator yang diharapkan pada pertemuan II adalah: 1) melakukan operasi hitung campuran perkalian dan pembagian bilangan dua angka. Selengkapnya rencana pembelajaran siklus II dapat dilihat pada lampiran 14 .

Berdasarkan hasil tindakan dari siklus I yang telah diuraikan di atas maka pada siklus II ini tindakan yang akan dilaksanakan yakni: 1) memperjelas penyampaian tujuan pembelajaran agar siswa lebih memahami materi yang akan di ajarkan. 2) Memperbanyak media dan diberikan kepada semua anggota kelompok sehingga masing-masing anggota kelompok dapat membaca dan memahami isi LKS dengan baik. 3) Masingmasing siswa dalam kelompok melakukan percobaan untuk penyelidikan. 4) Berusaha memaksimalkan pemakaian waktu dalam pembelajaran sesuai dengan rencana pembelajaran. 5) lebih memotivasi siswa agar dapat ikut aktif berdiskusi dalam kelompok.

Evaluasi hasil yang diperoleh pada siklus II mencapai rata-rata $88 \%$ dengan perincian sebagai berikut : 8 siswa (32\%) yang memperoleh nilai 100, 6 siswa (24\%) yang meperoleh nilai 90, 5 siswa (20\%) yang 
memperoleh nilai 85,3 pserta didik (12\%) yang memperoleh nilai 80,2 siswa (8\%) yang mendapat nilai 70,1 siswa (4\%) yang memperoleh nilai 60 . Ini berarti lebih dari $85 \%$ dari jumlah siswa yang mendapat nilai diatas 75 (88\% dari jumlah siswa).

Evaluasi hasil yang diperoleh pada siklus II $(88,2)$ mengalami peningkatan dibandingkan dengan tes pada siklus I $(77,2)$.. Kegiatan refleksi dilakukan secara kolaboratif antara peneliti, dan kepala sekolah, setiap pembelajaran berakhir. Pada kesempatan ini temuan dan hasil pengamatan peneliti dibahas bersama. Refleksi tindakan siklus II ini mencakup refleksi terhadap perencanaan, pelaksanaan, evaluasi dan hasil yang diperoleh oleh siswa.

Dari hasil belajar siswa yang meningkat, karena tidak ditemukan lagi siswa yang memperoleh nilai dalam $<70$. Nilai anak hanya berkisar di atas 70-100 dengan nilai rata-rata siswa 88. Dan dapat disimpulkan bahwa penelitian dalam pembelajaran siklus II telah melaksanakan tugas dengan baik. Hal ini dapat dilihat pada lampiran yaitu hasil belajar siswa pada siklus II. Dengan demikian penelitian ini berhenti pada siklus II dan tidak dilanjutkan pada siklus berikutnya.

\section{PEMBAHASAN}

Dari hasil penelitian pelaksanaan pembelajaran pendekatan matematika realistik pada pembelajaran melakukan operasi hitung campuran perkalian dan pembagian bilangan sampai dua angka pada mata pelajaran matematika kelas II Sekolah Dasar Negeri 22 Lubuk Alung Kabupaten Padang Pariaman. Dan terlihat dalam proses pembelajaran bahwa guru membuat rancangan pembelajaran dalam bentuk Rencana Pelaksanaan Pembelajaran (RPP). Susanto (2007:167) mengatakan bahwa "Rencana Pelaksanaan Pembelajaran (RPP) adalah penjabaran silabus ke dalam unit satuan kegiatan pembelajaran untuk dilaksanakan di kelas. Rencana Pelaksanaan Pembelajaran merupakan rencana operasional pembelajaran yang memuat beberapa indikator yang terkait untuk dilaksanakan dalam satu atau beberapa kali pertemuan".

Perencanaan yang disusun guru dalam penelitian terdiri dari beberapa komponen yaitu: 1) Standar Kompetensi, 2) Kompetensi Dasar, 3) Indikator, 4) Tujuan Pembelajaran, 5) Materi pokok, 6) Kegiatan pembelajaran, 7) Media dan sumber, 8) Evaluasi. Standar Kompetensi dan Kompetensi Dasar diambil dari Kurikulum Tingkat Satuan Pendidikan (KTSP) Matematika Kelas II Sekolah Dasar.

Berdasarkan perencanaan yang disusun pelaksanaan pembelajaran dilaksanakan sesuai dengan apa yang telah direncanakan, yang mana pada siklus I pembelajaran disajikan dalam dua kali pertemuan ( $5 \times 35$ menit). Pembelajaran pada siklus I dilaksanakan sesuai dengan tahap-tahap pembelajaran matematika realistik yaitu: 1) tahap pendahuluan, 2) tahap pengembangan model simbolik, 3) tahap penjelasan dan alasan, dan 4) tahap penutup. Berdasarkan catatan pada lembar observasi dan diskusi peneliti dengan pengamat penyebab dari masih rendahnya hasil belajar siswa pada siklus I secara garis besar adalah masih banyak siswa yang belum aktif dalam pembelajaran.

Berdasarkan hasil pengamatan aktivitas guru, guru kurang memberikan motivasi kepada siswa untuk menyampaikan ide/gagasan yang ditemukannya. Guru juga kurang membimbing siswa dalam menyimpulkan materi pelajaran. Oleh sebab itu sebaiknya gurulah lebih memotivasi dan membimbing siswa untuk menyampaikan ide/gagasan yang mereka temukan dalam melakukan operasi hitung campuran. Guru harus membimbing siswa untuk membuat simpulan pembelajaran dan membimbing siswa untuk dapat memindahkan permasalahan dalam matematika. Hal ini karena siswa baru pertama kali melaksanakan pembelajaran seperti ini.

Pembelajaran dipengaruhi oleh berbagai faktor seperti motivasi, kematangan, hubungan siswa dengan guru, kemampuan verbal, tingkat kebebasan, rasa aman, dan keterampilan guru dalam berkomunikasi. Oleh karena itu guru harus melakukan perbaikan dalam pelaksanaan pembelajaran disamping perbaikan pada RPP. Guru harus dapat memberikan motivasi kepada siswa dalam pembelajaran. Peran guru dalam membelajarkan siswa sangat besar, upaya menimbulkan motivasi anak untuk belajar sangat berat seperti yang diungkapkan oleh Rochman (dalam Rosna, 2006:45) bahwa: Peran guru dalam memberi motivasi anak adalah mengenal setiap siswa yang diajarkannya secara pribadi, memperlihatkan interaksi yang menyenangkan, menguasai berbagai metode dan teknik mengajar serta menggunakannya dengan tepat, menjaga suasana kelas supaya siswa terhindar dari konflik dan frustasi serta yang amat penting memperlakukan siswa sesuai dengan keadaan dan kemampuannya.

Dari hasil analisis penelitian siklus II sudah mencapai $88 \%$ dan nilai rata-rata kelas 88,2 . Berdasarkan hasil pengamatan siklus II yang diperoleh maka pelaksanaan siklus II sudah baik dan guru sudah berhasil dalam usaha peningkatan hasil belajar matematika tentang operasi hitung campuran melalui pendekatan realistik bagi kelas II SDN 22 Lubuk Alung Kabupaten Padang Pariaman.

Pada dasarnya, matematika adalah pemecahan masalah (problem solving), oleh sebab itu matematika sebaiknya diajarkan melalui berbagai masalah yang ada di lingkungan sekitar siswa. Dengan begitu siswa 
dapat terlatih berfikir dan berargumentasi. Melalui matematika, siswa dapat pula dibiasakan bekerja efisien, selalu berusaha mencari jalan yang lebih sederhana dan lebih mudah dipahaminya tanpa mengurangi keefektifannya.

Untuk mencapai hal tersebut sudah seharusnya guru mampu menciptakan pembelajaran yang sesuai dengan kebutuhan siswa. Selain itu guru juga harus memperhatikan keberhasilan siswa dalam memahami sesuatu dengan cara sesuai dengan tingkat kemampuan siswa. Guru bertugas membelajarkan siswa, maka guru haruslah menggunakan berbagai macam cara agar pembelajaran dapat bermakna bagi siswa, seperti menggunakan pendekatan realistik, dimana siswa terlibat dalam melakukan kegiatan pembelajaran dan siswa menemukan sendiri konsep matematika. Pendekatan realistik dapat menciptakan suasana belajar yang menyenangkan bagi siswa.

\section{KESIMPULAN DAN SARAN \\ KESIMPULAN}

Dari paparan data dan hasil penelitian serta pembahasan dalam Bab IV, maka peneliti dapat menarik kesimpulan dari penelitian ini yakni:

a. Pembelajaran matematika melalui pendekatan realistik terdiri dari 4 tahap. Pembelajaran menggunakan pendekatan realistik dibagi atas tiga kegiatan yaitu kegiatan awal, kegiatan inti, kegiatan akhir. Pada kegiatan awal dilaksanakan kegiatan tahap pendahuluan dan membagi kelompok. Pada kegiatan inti dilaksanakan tahap pengembangan model simbolik dan tahap penjelasan dan alasan. Pada kegiatan akhir dilaksanakan tahap penutup dimana siswa diarahkan untuk menyimpulkan pembelajaran dan memberikan tes akhir.

b. Pendekatan realistik dapat memotivasi siswa untuk belajar dengan gembira, bebas, aktif, dan produktif, sehingga kendala psikologis yang sering menghambat siswa seperti rasa enggan, segan, takut, dan malu dapat teratasi.

c. Siswa terlatih berbagi pengalaman, aktif dalam belajar, berani menyampaikan ide/gagasan yang ditemukannya, dan bersedia mendengarkan pendapat orang lain, serta mau menerima perbedaan pendapat.

d. Fungsi guru berubah dari seorang penyampai pengetahuan atau pemberi informasi menjadi fasilitator. Hal ini terlihat dalam penyajian pembelajaran guru yang semula selalu memberi penjelasan berubah menjadi fasilitator.

e. Bentuk pembelajaran dengan pendekatan realistik terhadap operasi hitung campuran dapat meningkatkan hasil belajar siswa. Meningkatnya hasil belajar siswa tersebut dapat dilihat dari rata-rata yang diperoleh pada siklus I yakni 77,2 dan pada siklus II mengalami peningkatan yaitu menjadi 88,2.

\section{SARAN}

Berdasarkan kesimpulan yang telah dicantumkan di atas, maka peneliti mengajukan beberapa saran untuk dipertimbangkan:

a. Bentuk pembelajaran matematika melalui pendekatan realistik layak dipertimbangkan oleh guru untuk menjadi pembelajaran alternatif yang dapat digunakan sebagai referensi dalam memilih pendekatan pembelajaran.

b. Bagi guru yang ingin menerapkan pembelajaran dengan menggunakan pendekatan realistik, disarankan memperhatikan hal-hal sebagai berikut:

1) materi pembelajaran disesuaikan dengan konteks sehari-hari siswa.

2) perlu lebih kreatif dalam merancang pembelajaran yang sesuai dengan situasi dunia nyata.

3) perlu memberikan perhatian, bimbingan dan motivasi belajar secara sungguh-sungguh kepada siswa yang berkemampuan kurang dan pasif dalam kelompok, karena siswa yang demikian sering menggantungkan diri pada temannya.

c. Guru perlu menyiapkan sarana dan prasarana yang dikenali siswa, karena akan mempermudah siswa memahami masalah.

d. Bagi peneliti selanjutnya disarankan untuk melakukan kajian mendalam tentang penerapan model pembelajaran dengan pendekatan realistik pada materi lain dalam matematika.

e. Kepada kepala Sekolah Dasar dan pejabat terkait kiranya dapat memberikan perhatian kepada guru terutama dalam meningkatkan hasil belajar dalam proses pembelajaran. 


\section{DAFTAR PUSTAKA}

Arjuna, Abang. 2007. Matematika Realistik. Dalam (http://darmosusianto.blogspot.com/ di akses 5 Maret 2009)

Awidyarso. 2009. Pendekatan Kontekstual. Dalam (http://awidyarso.files.wordpress.com diakses 28 Februari 2009)

Depdiknas. 2006. Kurikulum Tingkat Satuan Pendidikan Jenjang Pendidikan Dasar. Jakarta: Depdiknas

Erman, dkk. 2003. Strategi Pembelajaran Matematika Kontemporer. Bandung: FMIPA

Gregoria, Ariyanti. Pendekatan Matematika Realistik dalam Pembelajaran Matematika.(Online)(http://ariyanti.freehostia.com.wordpress/?p=31/ diakses 5 Maret 2009)

Karso. 2000. Pendidikan Matematika I. Jakarta: Universitas Terbuka.

Martinis, Yamin. 2007. Kiat Membelajarkan Siswa. Jakarta: Gaung Persada press

Max, A, Sobel dan Evan, M, Maletsky. 2004. Mengajar Matematika. Jakarta: Erlangga

Nurhayati, Rahayu. 2009. Matematika itu Gampang. Jakarta Selatan: Transmedia

Ritawati, Mahyudin dan Yetti, Ariani. 2007. Hand Out Metodologi Penelitian Tindakan Kelas. Padang: FIP UNP

Sardiman, A, M. 2006. Interaksi dan Motivasi Belajar-Mengajar. Jakarta: PT Raja Grafindo Persada

Sriyanto. 2009. Menebar Virus Pembelajaran Matematika Yang Bermutu.(Online) (http://209.85.175.104/search?q=cache:YekhwhEuahooJ/ diakses 5 Maret 2009)

Suharsimi, Arikunto, dkk. 2006. Penelitian Tindakan Kelas. Jakarta: Bumi Aksara

Sutarto, Hadi. 2007. Pendidikan Matematika Realistik. Banjarmasin: Tulip

Wardhani. 2007. Penelitian Tindakan Kelas. Jakarta: Universitas Terbuka

Wina, Sanjaya. 2008. Strategi pembelajaran berorientasi standar proses pendidikan. Jakarta: Kencana Prenada Media Group. 